\title{
The first department of medical psychology in the world and its impact on medical education
}

\author{
José A.S. Crippa, (iD Jaime E.C. Hallak iD \\ Universidade de São Paulo, Ribeirão Preto, SP, Brazil.
}

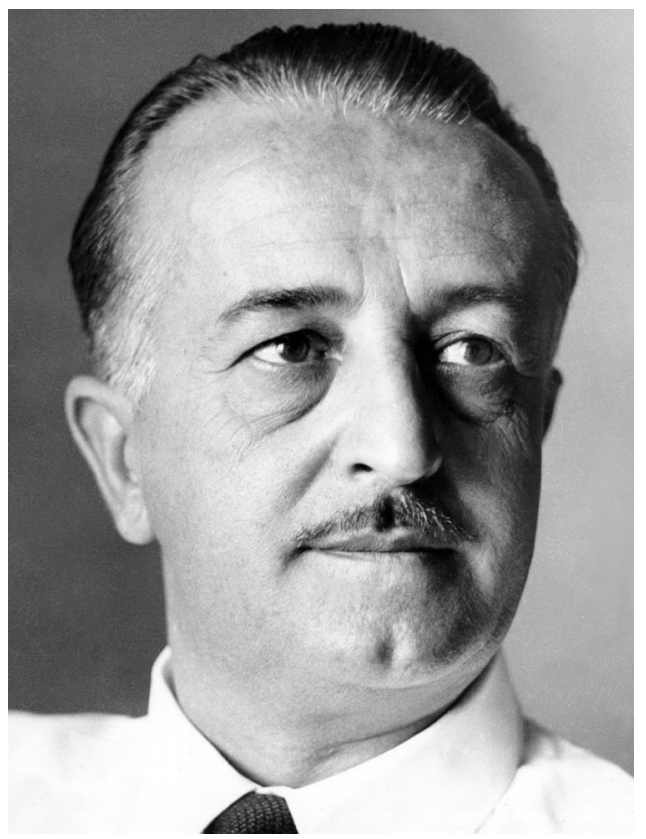

Dr. Zeferino Vaz (circa 1952)

Source: Collection of the Ribeirão Preto School of Medicine of the Universidade de São Paulo (FMRP-USP).

According to the international literature, the first Department of Medical Psychology was created by the University of Oregon Medical School in 1957. The historic relevance of this event - a landmark in the valorization of humanism and multidisciplinarity in medical education has been celebrated through articles, American Psychological Association conferences, and book chapters, as well as a meritorious distinction on the University of Oregon homepage. However, the recent publication of Faculdade de Medicina de Ribeirão Preto da Universidade de São Paulo: Primeiras Décadas ${ }^{1}$ (Ribeirão Preto Medical School of the University of São Paulo: Early Decades), organized by professors from this institution, documents a fact that went mostly overlooked until now. In 1956, that is, 1 year before the University of Oregon,

Correspondence: José A.S. Crippa, Hospital das Clínicas da Faculdade de Medicina de Ribeirão Preto, Av. Bandeirantes, 3900, CEP 14049-900, Universidade de São Paulo, Ribeirão Preto, SP, Brazil.

E-mail: jcrippa@fmrp.usp.br

Submitted Aug 02 2021, accepted Aug 11 2021, Epub Oct 292021. the Ribeirão Preto Medical School (FMRP-USP) was actually the first to create a Department of Medical Psychology.

The department was conceptualized by Dr. Zeferino Vaz (1908-1981), the founder and director of the medical school, who went on to create both the Universidade de Campinas and the Universidade de Brasília). This is just one of the pioneering disciplines that the institution has created since its foundation, helping transform medical education in Brazil and abroad.

Recently recovered letters archived at FMRP-USP show that Zeferino Vaz sought the participation of the most prominent psychoanalysts of the time, including Hanna Segal (1918-2011), British psychoanalyst and follower of Melanie Klein, and Emilio Servadio (19041995), one of the pioneers of psychoanalysis in Italy.

In those early times, Dr. Vaz highlighted the broad importance of mental health in medical training, stating that: "Human psychology is forgotten in our universities, when no one in a civilized country denies the deep relevance of psychic factors in the behavior of man and society, as well as in the development of the most severe diseases that affect man in modern days" (in Portuguese, "A psicologia humana é esquecida nas nossas universidades, quando ninguém, em país civilizado, nega mais o profundo significado dos fatores psíquicos no comportamento do homem e da sociedade, assim como no desenvolvimento das mais sérias doenças que afetam o homem na era moderna"). ${ }^{2}$ Thus, Vaz anticipated the future by envisioning the importance of psychotherapy techniques, behavioral and cognitive modification, family and interpersonal therapy, etc., in the management of chronic illnesses, in the reduction of physical and emotional symptoms, and in the management of emotional aspects of different general and psychiatric conditions. This contributed to the training of better, modern doctors, in line with the expectations of contemporary society, leading to a holistic view of patients. This has perhaps been even more important during the coronavirus disease 2019 (COVID-19) pandemic, in which environmental, social, psychological, and biological factors have led to new challenges in the training of present and future physicians.

How to cite this article: Crippa JAS, Hallak JEC. The first department of medical psychology in the world and its impact on medical education. Braz J Psychiatry. 2022;44:223-224. http://dx. doi.org/10.1590/1516-4446-2021-2155 
The FMRP-USP Department of Medical Psychology was initially headed by Chilean psychoanalyst Sérgio Rodriguez Gonzáles, followed by Chilean psychiatrist and psychoanalyst Hernan Ramon Davanzo Corte (1957 to 1965). The department was later expanded to include psychiatry and, in 1969, merged with the Neurology Department to form the Department of Neuropsychiatry and Medical Psychology, recently renamed the Department of Neuroscience and Behavior.

The FMRP-USP Medical Psychology course has been offered continuously since 1956 - three decades before becoming a mandatory subject in the Brazilian National Guidelines for Medical Schools. Currently, the Psychology Unit of the Department of Neuroscience and Behavior offers nine undergraduate courses, three graduate education programs and a number of different programs in training, research, extension, and administration at FMRP-USP.

\section{Acknowledgements}

JASC and JECH are recipients of research fellowships from Conselho Nacional de Desenvolvimento Científico e Tecnológico (CNPq). The funders had no role in the design and conduct of the study; collection, management, analysis, and interpretation of the data; preparation, review, or approval of the manuscript; and decision to submit the manuscript for publication.

\section{Disclosure}

JASC is listed as a coinventor of the patent "Fluorinated CBD compounds, compositions and uses thereof. Pub.
No.: WO/2014/108899. International Application No.: PCT/IL2014/050023," Def. US number Reg. 62193296; July 29, 2015; INPI on August 19, 2015 (BR1120150 164927; Mechoulam R, Zuardi AW, Kapczinski F, Hallak JEC, Guimarães FS, Crippa JAS, Breuer A). Universidade de São Paulo (USP) has licensed this patent to Phytecs Pharm (USP Resolution No. 15.1.130002.1.1) and has an agreement with Prati-Donaduzzi to "develop a pharmaceutical product containing synthetic CBD and prove its safety and therapeutic efficacy in the treatment of epilepsy, schizophrenia, Parkinson's disease, and anxiety disorders." JASC is a member of the international advisory board of the Australian Centre for Cannabinoid Clinical and Research Excellence (ACRE)/National Health and Medical Research Council (NHMRC). JASC and JECH have received travel support to attend scientific meetings and personal consultation fees from BSPGPharm. JASC and JECH are listed as coinventors of the patent "Cannabinoid-containing oral pharmaceutical composition, method for preparing and using same," INPI on September 16th, 2016 (BR 112018005423-2).

\section{References}

1 Rodrigues MLV, Marchini JS, Salgado HC, Carlotti Jr CG, editors. Faculdade de Medicina de Ribeirão Preto - USP: primeiras décadas. Ribeirão Preto: FUNPEC-Editora; 2018. http://www.fmrp.usp.br/wpcontent/uploads/sites/356/2018/02/E-book-Primeiras-Decadas-052019.pdf

2 Ferraz JBF. Faculdade de Medicina de Ribeirão Preto - USP: criação e impacto no ensino médico. Ribeirão Preto: FUNPEC-Editora; 2005. 